ИЗВЕСТИЯ АКАДЕМИИ НАУК ЭСТОНСКОИ ССР. ФИЗИКА * МАТЕМАТИКА PROCEEDINGS OF THE ACADEMY OF SCIENCES OF THE ESTONIAN SSR. PHYSICS * MATHEMATICS

$1987,36,4$

\title{
ОСОБЕННОСТИ ВИБРОННОЙ СТРУКТУРЫ СЕЛЕКТИВНЫХ СПЕКТРОВ ФЛУОРЕСЦЕНЦИИ ПЕРИЛЕНА, ЗАКЛЮЧЕННОГО В МАТРИЦУ ДНК
}

1. RENGE, K. MAURING. PERULEENI VIBROONSELEKTIIVSETE FLUORESTSENTSISPEKTRITE STRUKTUURI ISEARASUSED DNH MAATRIKSIS

I. RENGE, K. MAURING. PECULIARITIES OF VIBRONIC STRUCTURE IN SELECTIVELY EXCITED FLUORESCENCE SPECTRA OF PERYLENE INTERCALATED IN DNA MATRIX

(Представил К. К. Ребане)

1. Полициклические ароматические углеводороды (ПАУ) образуют комплексы с ДНК, встраиваясь, вероятно, между витками двойной спирали в гидрофобной области азотистых оснований (т. н. интеркаляция) $\left[{ }^{1,2}\right]$. Ковалентное связывание метаболически активированного ПАУ с ДНК представляет собой ключевую стадию канцерогенного действия ряда ПАУ $\left[{ }^{3}\right]$. Главным образом в аналитических целях исследовались узколинейчатые спектры флуоресценции некоторых ПАУ, химически связанных с ДНК, используя селективное лазерное возбуждение в УФ-области $\left[{ }^{4}\right]$. В последнее время появился интерес к низкочастотным колебаниям биомакромолекул, в частности ДНК, которые изучались методами микроволнового поглощения [5] и комбинационного рассеяния $\left[{ }^{6}\right]$.

Настоящая работа была предпринята с целью выявления особенностей в узколинейчатых спектрах флуоресценции примесных центров, нековалентно интеркалированных в матрицу ДНК. В качестве ПАУ был выбран перилен, ибо для него уже были зарегистрированы тонкоструктурные спектры в обычных средах, при возбуждении в области $0-0 \quad S_{1}-S_{0}$-перехода линией $\mathrm{He}-\mathrm{Cd}$-лазера $(441,6$ нм) [7].

2. Для солюбилизации крайне труднорастворимого ПАУ дно небольшого химического стакана покрывали тонким слоем микрокристаллов перилена («Aldrich», gold label) путем выпаривания его эфирного раствора, затем добавляли воду и ДНК (из тимуса теленка, «Worthington Biochem. Corp.») - 3 мг/мл. Раствор перемешивали при комнатной температуре в течение суток и затем центрифугировали в течение 2 ч при 20 тыс. g. Раствор заливали в 1 мм кварцевую кювету, которую устанавливали в оптическом криостате в парах гелия $(T=5 \mathrm{~K})$. Возбуждение производили Не-Сd-лазером ЛПМ-11 ( $\lambda=$

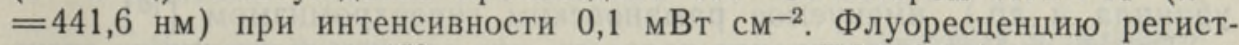
рировали под углом $45^{\circ}$ через монохроматор ДФС-24 (ширина щелей 1,5 Å) с помощью ФЭУ D341/350Q («ЕMI»), работающего в режиме счета фотонов. Сигнал записывали в многоканальном анализаторе «Nokia LP-4900 B». Спектральная чувствительность регистрационной аппаратуры калибровалась с помощью эталонной лампы накаливания. 


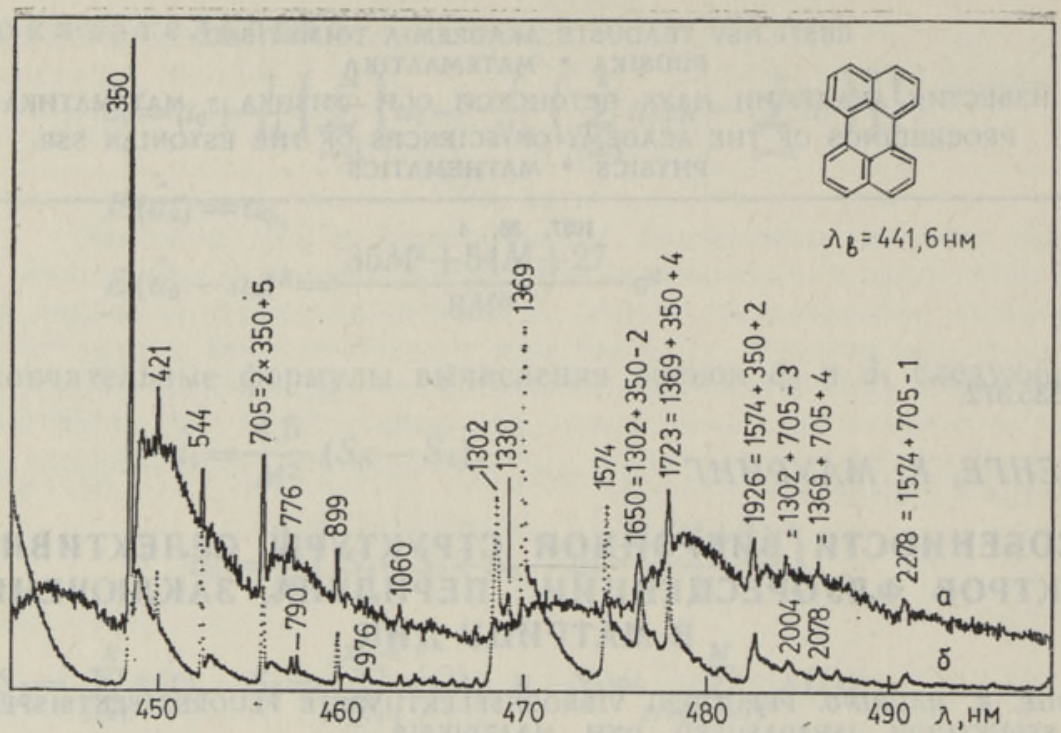

Исправленные спектры флуоресценции перилена, интеркалированного в матрицу ДНК (a) и в стеклообразную смесь метанол-этанол (1:1) (б) при 5 К. Длина волны возбуждения 441,6 нм (частоты колебаний перилена в основном состоянии указаны в $\left.\mathrm{cm}^{-1}\right)$. Спектры нормированы по максимуму $350 \mathrm{~cm}^{-1}$.

3. Анализ спектров флуоресценции перилена (рисунок) в водном растворе ДНК $(a)$ и в стеклообразной смеси метанол-этанол $(1: 1)$ (б), показывает, что в спиртовом стекле контраст линий по отношению к фону выше. Это, по-видимому, не свидетельствует об усилении электрон-фононного взаимодействия в матрице ДНК, а отражает известное обстоятельство, что при интеркалировании имеет место сдвиг $0-0$-полосы ПАУ на 5-10 нм в длинноволновую область $\left[{ }^{2}\right]$. Так, при неселективном УФ-возбуждении 0 -0-полоса флуоресценции перилена, заключенного в ДНК, имеет максимум при $\lambda_{\text {макс }}=445$ нм, в то время как в спирте $\lambda_{\text {макс }}=441$ нм. В среде ДНК монохроматический свет с $\lambda=441,6$ нм возбуждает коротковолновый край неоднородно уширенной полосы, где вклад бесфононных линий в спектре поглощения относительно невелик.

Более существенны различия спектров $a$ и б в области колебательных линий $1300-1600 \mathrm{~cm}^{-1}$. Наблюдается общее падение интенсивности вибронных переходов, а также относительное ослабление бесфононных линий на данном участке спектра. Тем не менее сильнейшие полносимметричные плоские колебания $A_{g}$ типа молекулы перилена $\left[{ }^{8,9}\right]$ с частотами 1302,1369 и $1574 \mathrm{~cm}^{-1}$ не исчезают при комплексообразовании, ибо их комбинации с модами 350 и $2 \times 350+5=705 \mathrm{~cm}^{-1}$ видны в спектре с неизменными интенсивностями. Примечательно, что в спектре КР чистой ДНК в воде также обнаружены интенсивные пики при 1304 (аденин), 1378 (тимин, гуанин, аденин) и $1580 \mathrm{~cm}^{-1}$ (гуанин, аденин), приписанные плоским колебаниям азотистых оснований $\left[{ }^{10}\right]$. При упорядочении полинуклеотидных цепей в растворе имеет место падение интенсивности ряда мод $\left(1301 \mathrm{~cm}^{-1}\right.$ аденина, 1236 и $1660 \mathrm{~cm}^{-1}$ урацила и др.), именуемое рамановским гиперхромизмом $\left[{ }^{10}\right]$.

Эти факты дают основание полагать, что влияние матрицы на спектры флуоресценции отражают сильное взаимодействие перилена с нуклеотидами, приводящее к быстрой миграции колебательной энергии от ПАУ к нуклеотидам, к сокращению времени жизни вибронного подуровня и к его уширению. Вероятно, при тесном контакте и параллель- 
ной ориентации примесного центра и азотистых циклов нуклеотидорิ можно говорить о формировании общей колебательной зоны. Все же установление конкретного механизма взаимодействия предполагает более детальное спектроскопическое изучение интеркалированных ПАУ.

4. Дальнейшее рассмотрение спектра перилена в ДНК выявляет ряд видоизменений слабых линий. Так, вместо двух пиков в стеклах при 780 и $793 \mathrm{~cm}^{-1}$ в ДНК виден лишь один максимум при $776 \mathrm{~cm}^{-1}$. Уникальной для замороженного раствора является частота $979 \mathrm{~cm}^{-1}$. Добавим, что спектры в протонном стекле метанол-этанол и в неполярном апротонном стекле диизоамилового эфира можно считать идентичными. Значит, возмущение молекулы ПАУ водородными связями (л-электронная система может выступать в качестве акцептора $H$-связи) и полем диполей молекул растворителя незаметно отражается в частотах и интенсивностях вибронного спектра. Естественно предположить, что причиной изменения частот в интервале $400-1000 \mathrm{~cm}^{-1}$, часть которых, вероятно, неплоские $\left[{ }^{11}\right]$, служит жесткая фиксация ПАУ внутри спирали ДНК.

В заключение отметим, что в настоящем сообщении продемонстрированы некоторые новые возможности применения лазерной спектроскопии примесных центров, введенных в качестве зондов в биомакромолекулы, для исследования колебательных состояний этих нестандартных матриц. Большой интерес для биофизики представляют низкочастотные коллективные возбуждения в регулярных полимерных цепях (ДНК, белки), взаимодействие которых с электронными переходами примеси нуждается в дальнейшем исследовании.

Авторы благодарны |Р. Авармаa| за внимание к работе и А. Суйсалу за предоставление калибровочного графика спектральной чувствительности системы.

\section{Л И Т Е Р А Т У Р A}

1. Green, B., McCarter, J. A. J. Mol. Biol., 29, 447-456 (1967).

2. Boyland, E., Green, B., Liu S.-L. Biochim. Biophys. Acta, 87, № 4, 653-663 (1964).

3. Nicolini, C. (ed.) Chemical Carcinogenesis. New York, Plenum Press, 1982 ,

4. Sanders, M. J., Cooper, R. S., Jankowiak, R., Small, G. J., Heisig, V., Jeffrey, A. M. Anal. Chem., 54, 816-820 (1986).

5. Edwards, G. S., Davis, C. C., Saffer, J. D., Swicord. M. L. Phys. Rev. Lett., 53, № $13,1284-1287$ (1984).

6. Lindsay, S. M., Powell, J. W., Rupprecht, A. Phys. Rev. Lett., 53, № 19, 1853-1855 (1984).

7. Personov, R. I., Al'shits, E. I., Bykovskaya, L. A. Opt. Comm., 6, № 2, 169-173 (1972).

8. Шпольский Э. В., Персонов Р. И. Опт. и спектр., 8, № 3, 328-337 (1960); Персонов Р. Н., Вальдман М. М. Опт и спектр., 19, № 4, 531-534 (1965).

9. Ковнер М. А., Терехов А. А., Бабков Л. М. Опт. и спектр., 33, № 1, 74-77 (1972); Whitmer, J. C., Cyvin S. J., Cyvin B. N. Z. Naturforsch., 33A, № 1, 45-54 (1978).

10. Small, E. W., Peticolas, W. L. Biopolymers, 10, № 8, 1377-1416 (1971).

11. Бабков Л. М., Ковнер М. А., Ренц В. Б. Опт. и спектр., 34, № 3, 615-617 (1973).

Институт физики

Академии наук Эстонской ССР

Поступила в редакцию

2/III 1987 